\title{
The service-learning and the humanisation of the academic curriculum in economics
}

\author{
Orlando Petiz Pereira* $\bullet$ Carlos Arriaga Costa
}

Departamento de Economia, Escola de Economia e Gestão, Universidade do Minho, Portugal.

${ }^{*}$ Corresponding author. E-mail: orlandop@eeg.uminho.pt.

Accepted 16 $6^{\text {th }}$ August, 2019.

\begin{abstract}
The teaching-learning methodologies based on service learning are examples of social and curricular innovation to improve well-being, integration and social cohesion. An academic curriculum based on service-learning rests upon a structured interdisciplinary. It produces creative plasticity, which enhances the production of creative personal, social, emotional, cognitive and spiritual knowledge. However, the curricula available within the Undergraduate Degree Programmes in Economics are still based on dominant economic models that favour quantitative approaches. We focus on the introduction of Service Learning into the academic curriculum, as an instrument of humanisation of the teaching of economics. The study uses qualitative methods of data collection and analysis, whilst resorting to group interviews with content analysis. All participants are faculty and researchers of Economics of the University of Minho. The results underline the importance of the humanisation concept of the economy. They underline the need for the establishment of interactions between the university, the students and the community, whose effects are spreading to the increase in social responsibility, leadership and economic sustainability. Nevertheless, it still prevails some apprehension on the part of teachers about their operationalisation and success.
\end{abstract}

Keywords: Service learning, university, community, academic curriculum.

\section{INTRODUCTION}

Over the past few years, higher education institutions have made some efforts to provide their students with rewarding experiences through curricular real projects (Podeschi, 2016). Although such projects are a curricular novelty associated with the solidarity commitment of universities to prepare citizens committed to people and the environment (Domínguez, 2009), these are not yet current practices in the University. Hence, the concern to develop in the student an ethical profile committed to sustainable development. It helps also to transform the social, political, economic and cultural structures, whilst aligning them with the goal of social justice. This is the feeling as materialised by Domínguez (2009:65) when considering that "education in the 21st century urges the University to be ever more solidary with service to the community, work to eradicate poverty, intolerance, violence, illiteracy, hunger and fight for environmental sustainability"1. According to lerullo and Maglioni (2015), educational organisations and the community are not rivals and they cannot be seen in a dichotomous relationship. They participate in horizontal solidarity and collective practices focused on global well-being and citizenship objectives. In this way, the implementation of Service-Learning implies to break with routines installed in institutions and society and change the linear vision of the material things and prioritise essential issues of life and society. Such objectives require the breaking with solidary frail feelings and enhancing low esteem behaviours and poor autonomy, accountability and cooperation practices.

\footnotetext{
${ }^{1}$ Our translation.
} 
Based on the importance of the learning-teaching methodology of Service-Learning (SL), this study aims at stimulating a lengthy debate within the University, especially for the teaching of Economics, in order to construct a humanitarian intervention student profile in the different socio-economic areas. In this context, it is important to relate it to the University extension, as well as to inquire about the sensitivity of university professors envisaging its inclusion in the academic curriculum. As a methodological path, the empirical study is based on qualitative methods of data collection and analysis. We resort to the use of group interviews with content analysis. There were two Focus Groups, where all participants were faculty teachers and researchers of the Department of Economics, School of Economics and Management, University of Minho.

\section{THE SERVICE LEARNING: ALTERNATIVE TEACHING AND LEARNING METHODOLOGY}

Teaching-learning methodologies based on service learning or in community projects are outstanding examples of social innovation and cutting-edge curricula that spring from human creativity to improve well-being and social integration and cohesion. Nonetheless, these service learning practices in higher education may develop into various very strong concepts (García García, Cotrina García, 2015). They respond to identified social needs and they answer to the lack of interest students seem to have in the traditional teaching and learning models. They provide synergy and efficiency gains in the application of scarce resources, strategic value and importance in the economy, and they steer cooperation amongst all economic actors in the rebuilding of a society of mutual respect. In this aspect, the methodologies of social nature seem relevant because they inspire the students to perform community service with business and social entrepreneurs (Desplaces et al., 2006). In NCES (1999) the term community service is used as a proxy for service learning, thus it is defined as a service provided by the students, recognised and organised by the schools, but outside and unrelated to the curriculum. The emphasis is that such community service can be mandatory or voluntary but usually it does not entail learning objectives, critical analysis and reflection. It is a service that can be performed inside or outside of the school, as it is the example of clubs that exist in schools to boost extracurricular activities.

The community service may have different names, such as social service, university communal work, community professional practice curriculum extension, educational volunteering work, service learning, community service to the nation, philanthropic intentionality, solidary service activities, practices of solidarity (Tapia, 2010). Therefore, we must distinguish the service learning of other practices of community service, because they seek to achieve different objectives. While a pedagogical orientation, the service learning combines volunteering work with well-structured learning opportunities (Heffernan, 2001). Yet, its introduction in the curriculum is not a sufficient condition to ensure success, because this implies changes in the curricular units' syllabus, in the ways to boost classes, in the professors' roles and behaviours/attitudes. However, if the community service can occur inside or outside of the curriculum, a few questions do materialise. Will it be beneficial to the student and society to include the service learning explicitly in the academic curriculum? What is the benefit of this inclusion? Actually, its inclusion in the academic curriculum is a challenge to teachers, students and society mind-sets, to incorporate changes to the level of dialogue and to implement activities involving equity, difference, inclusion, justice and efficient use of resources for the benefit of the community. The application of the service learning does also bring some imbalance to the normal functioning of educational institutions because it "forces" to reflect and to redefine their processes, objectives and mission. It also requires a culture of change in what regards the institutional rigidity curricular portfolio (García and Cotrina, 2015), which may become a source of discomfort to the more conservative and technocrat agents. Notwithstanding the aforementioned constraints, to which we associate the "creative destruction", the service learning features gains in terms of personal, cognitive, interpersonal, social and moral development, that have contributed to increasing considerably the studies on the service-learning in recent decades (Hegarty and Angelidis, 2015; Wang and Rodgers, 2006).

Celio et al. (2011) consider that the service learning must be part of the academic curriculum because evidence demonstrates that the involved students have significant gains of attitudes about themselves, toward the university, others and the community and they become richer in social skills, humanised leadership and empathy. Lee (2012) shares the same guidelines and emphasises the inclusion of service learning in the academic curriculum, due to its positive impact on (i) academic learning, (ii) interpersonal development, and (iii) personal development. In terms of personal development, he considers that it enhances the development of practical, intrapersonal, interpersonal, leadership, and social skills. This plethora of skills enshrines the cultural capital of a region. It stresses that the service learning bridges the gap between traditional education and strategic education of the 21st century, which is committed to everything that affects the wellbeing of the planet, ranging from the balance amongst citizens and all other living beings. Amongst the various outputs of the service learning, Yorio and Ye (2012) highlights three of them: (i) Understanding Social Issues, (ii) Personal Insight and (iii), Cognitive Development, according to Table 1. 
Table 1. Learning outcomes of service-learning.

\begin{tabular}{lll}
\hline Learning outcome & Definition & Sample measures \\
\hline $\begin{array}{l}\text { Understanding social } \\
\text { issues }\end{array}$ & $\begin{array}{l}\text { An individuals' frame of reference } \\
\text { that guides decision making in } \\
\text { terms of complex social issues. }\end{array}$ & $\begin{array}{l}\text { Diversity and cultural awareness and sensitivity; } \\
\text { perceptions of homeless, elderly, disabled, different } \\
\text { races or cultures; ethical and moral values and } \\
\text { decision making; interpersonal skills; understanding } \\
\text { of the needs of the community; understanding how to } \\
\text { help the community; a desire to engage in future } \\
\text { service activities in terms of both a feeling of } \\
\text { responsibility and a commitment to do so. }\end{array}$ \\
& $\begin{array}{l}\text { An individual's perception of self } \\
\text { Personal insight }\end{array}$ & $\begin{array}{l}\text { Identity; awareness of oneself in terms of strengths } \\
\text { and weaknesses; career aspirations; self-efficacy; } \\
\text { self-esteem; determination; persistence. }\end{array}$ \\
& $\begin{array}{l}\text { Task and skills development and } \\
\text { academic achievement. }\end{array}$ & $\begin{array}{l}\text { Management skills development; writing skills; } \\
\text { problem-solving skills; critical-thinking skills; GPA; } \\
\text { course performance. }\end{array}$ \\
\hline
\end{tabular}

Source: Yorio and Ye (2012:11).

According to Copaci and Rusu (2016:3), the service learning is an enrichment of the curriculum. It fosters civic responsibility and emerges as a means of development of democracy and of democratic participation. As there is no prescription for the application of service learning, several alternative perspectives:

(i) Frequency Service Learning (SL) independent course;

(ii) Service Learning (SL) embedded in a course curriculum;

(iii) Service Learning (SL) as a summer program;

(iv) Service Learning (SL) as professional experience.

The different possibilities for embedding Service Learning in the curricula would allow for a better structure of the individual and society. Hence, this requires time:

- The observation and investigation of the needs of the community.

- Planning of the service to provide.

- The action and operationalisation of the tasks.

- Reflection, sharing and analysis.

- The presentation and demonstration of the impacts of service learning.

- The joy derived from the experience and the results achieved.

"Time" depends on the type of project to implement. Nevertheless, in a service learning programme, the duration of students' involvement in the community life varies and it may account for a year (Bamber and Hankin, 2011). However, before the student's participation in the community life, there should be conducted lengthy discussions and open dialogue on the community and society in general terms. This would be important to discuss issues such as poverty, exclusion, suffering, loneliness, climate change, inter alia. For an efficient application of service learning, the identification of problems and the treatment of each stage would be necessary, but not a sufficient condition, for its success.

Among the various existing learning styles, Eyler et al. (1996) are pleased with the service learning embedded in the curriculum because it would favour discussions that may help to structure and develop collectively the group. This assumption can unlock the isolation the student may feel and that exists in educational institutions. The reflection is the key to the success of learning (Bjornestad et al., 2016) and the development of the student grows consistent with the answers to the questions: What? So what? Now what? (Burke and Bush, 2013).

Although important, the reflection is not enough to ensure the success of service learning (Kiely, 2005; Swords and Kiely, 2010; Burke and Bush, 2013). Whether formal, non-formal or informal, the reflection must take into account the students ' evaluation, the students' performance assessment, feedback from the staff of the Agency of cooperation, while conducting research on the service learning and discussions with colleagues (Bringle and Hatcher, 1995). This reflection inspires questions about the process, about the obstacles that might materialise. It also makes an assessment of the strengths and weaknesses of the project's outcomes. This process allows the student and the educational institution to enrich themselves with more knowledge and practical wisdom, which complements and supports the theoretical component received in the classroom. However, the reflection is not restricted to a phase but rather crosscutting all of them. The reflection gets particular relevance before the start of the project because this is the phase of conception, projection, identification of weaknesses and potential of those 
Table 2. Critical success factors for service learning.

\begin{tabular}{ll}
\hline Learning critical success factor & Source \\
\hline $\begin{array}{l}\text { 1. Necessary reflection or feedback } \\
\text { 2. Reflection by all stakeholders }\end{array}$ & $\begin{array}{l}\text { McAndrew (2001), the University of Pittsburgh at Johnstown 2003, Mclver } \\
\text { and Rachell 2002 }\end{array}$ \\
$\begin{array}{l}\text { Citrin (1993) } \\
\text { 3. Grading on actual learning } \\
\text { 4. Careful project selection }\end{array}$ & $\begin{array}{l}\text { McEachern (2001), Valerius and Hamilton (2001) } \\
\text { 5. The relevance of the project to the intended } \\
\text { academic program }\end{array}$ \\
$\begin{array}{l}\text { 6. Partnership between stakeholders } \\
\text { 7. Optional involvement }\end{array}$ & Eby (1998) \\
8. Balanced interests of all stakeholders & Gujarathi and McQuade (2002) \\
9. Careful selection of stakeholders & Eby (1998) \\
\hline
\end{tabular}

Source: Wilcox and Zigurs (2003:5).

involved and of the community, identification of the instruments to develop the tasks, inter alia. Similarly, in its terminus reflection, it gains particular importance as it is the moment during which it occurs the survey of the whole process, analyse the achieved objectives with the planned ones. It is when the research identifies the gap of unachieved objectives and when it analyses why such a result and which are the possible alternatives to implement.

Finally, embedding the methodology of service learning in the curriculum implies to take care and increase precautions because it is important to respect the critical success factors of the project. If this does not happen, the process will be a strong contender for failure. Hence, Wilcox and Zigurs (2003:5) identified nine critical success factors in the implementation of service learning, as summarised in Table 2.

\section{METHODOLOGY: INSTRUMENT AND SAMPLE}

The empirical study of this work is based on qualitative methods of data collection and analysis, using group interviews (Focus Group) with content analysis, by resorting to the use of a semi-structured interview script. In this study, we understand Focus Group as a discussion among specialised individuals, while contemplating their education, their professional experience, their knowledge and application of alternative learning-teaching methodologies. The individuals belonging to the focus group are guided by seeking to innovate in their pedagogical practices with a view to better their performance, both from the teacher and the students or the institution. In this light, we relied upon teachers profiling those characteristics. For convenience reasons, all participants are faculty of the Department of Economics, School of Economics and Management, University of Minho, according to different scientific areas in the field of Economics: Labour Economics, Environmental Economics, Social Economics, Financial and Banking Economics, Econometrics, Macroeconomics and Microeconomics. The researchers plan to listen to the opinion of their co-workers - faculty - on humanisation in teaching economics and on the appropriateness of the inclusion of service learning in the Undergraduate Degree in Economics. This is an instrument of the qualitative methodology that resorts to small groups and should be moderated by one or more facilitators (Guerra, 2006). In this research, two Focus groups were held and moderated by two facilitators. The first group gathered six individuals and the second five. The size of each group is consistent with the literature, which considers that the size of each group should oscillate between 4 and 12 individuals (Guerra, 2006; Patton, 2002).

We focused on the interpretation and the meaning of objects to analyse. In this research, the reading and analysis of the results of the interviews take advantage of a content review process that, according to Patton (2002), is a method used in qualitative research to identify and define the themes that emerge from the interview. In this sense, according to the method, we proceeded to the encoding of the text category recognition. We identified and analysed, in-depth, the contextual meanings in the examples of the teaching of Economics as a focus to the study in order to understand a symbolised world (Rudy et al., 2010). This qualitative research methodology proceeds to the treatment of information through in-depth interviews (in this case, in a group) that stems from semi-structured interview grids. Whilst following the indications of Rudy et al. (2010), Guerra (2006) and Patton (2002), the interviews were recorded in audio. They were subsequently transcribed in full. We proceeded to the first pre-analysis reading, with the aim of identifying terms repeated throughout the text and understanding the meaning of the discussion among the different individuals of the group (lengthy analysis of the material). We then proceeded to a second reading considering the terms previously collected to construct identifying categories of the various problems under study (treatment). We identified the categories as 
expected, according to Bardin (1977), to interpret their meaning and potential associations, which are explicit in the results and in the discussion.

\section{RESULTS}

Through content analysis we identified the following categories, on the assumption that the academic curriculum is more sensitive to humanisation:

(i) Measurement of Economy: Quantitative vs. qualitative

(ii) Economic rationality: objectivity vs. subjectivity

(iii) Competition: Competition vs. cooperation

(iv) Utility/Usefulness

(v) Leadership: lead vs. guide

(vi) Social responsibility

(vii) Higher education orientation

\section{Measurement of Economy: Quantitative vs. qualitative}

The teaching of Economics often uses quantitative methods as a tool for economic measurement. In the case of econometrics, whose teachers give importance and frequently use prediction models, it is seen with greater difficulty the introduction of individual interaction themes with society and with happiness, while a socioeconomic variable. This is the actual state-of-the-art in the teaching of economics. This is why it underlines the objective, rational and competitive aspects. However, this kind of orientation is facing difficulties deriving from the metamorphosis of society, where qualitative analysis seems to have some explanatory power in the performance of an economic analysis. Hence, the discussion has raised the term "externality" to explain the deviations to the economic objectivity. One of the teachers, who participated in the Focus Group, resists to the introduction of this type of variables because "in principle, happiness is not usable in Econometrics". Indeed, in his opinion, the "concept of happiness is very subjective and depends a lot on each person". Another teacher, however, argued, "The consumer utility is also subjective and it is treated in economics and Econometrics, as such why cannot one model happiness?" Again, the professor of Econometrics continues on to object by asking questions about the handling of this type of variables for the economic forecast and says: "but it will be possible to forecast with those variables? And if this is not possible then what is the purpose of realising economic studies?" Another econometrician considered that everything could be modelled, which contradicts the traditional theory because, in his opinion, everything can be modelled and be the object of economic analysis by means of variables that economic theory has been neglecting so far.

\section{Economic rationality: objectivity vs subjectivity}

What are the relevant values in economics? The foundation of economic models is based on "economic rationality". This considers that individuals take only rational decisions based on logical operations to achieve its maximum utility. Therefore, the centre of the decision in economic science is the individual and not society. However, the individual is in a social equilibrium and not in isolation. Hence, the academic discussion that has arisen about happiness in the economy has been a launching platform for better performances. This stance led participants to the importance of social harmony and how can the degree in economics contribute to this goal. In this respect, the question of whether it makes sense or not to reflect on the humanisation in the economy and how to apply it to the teaching of economics and how to introduce economic models. One of the teachers said that this issue is already embedded in the curriculum as examples and not as a topic within the syllabus. Another professor argued that the economy continues to be marked by two major approaches, the so-called positive and normative economics.

\section{Competition: competition vs. cooperation}

The economic optimisation models consider that the value of the competition is structuring in the economy and is associated with the values of efficiency. There is a widespread opinion of the importance of efficiency in economic models, where the values associated with the competition seem to overlap other values. This orientation is in line with the individual satisfaction of the economic agent. However, in recent decades, the value of cooperation has been introduced in a more incisive way in the area of social welfare and economic sustainability. The question is to determine as to why the value of cooperation could be considered in such a model or not. One of the teachers said that, in the class setting, it is only the values of competition that are transmitted to the students, while acknowledging that this value is a starting point for the discussion of all the economic theory. On the other hand, the existence of externalities is also part of the economic discussion, and the trade-off, concept of economics, which implies to give up something to get another "thing", eventually changing material for immaterial values, values as solidarity, selflessness, kindness, cooperation (...), that are also part of the construct of happiness. This approach, in the opinion of a professor, is already being introduced in classes on social, environmental and labour economics, where they convey values of competition, but also of cooperation.

\section{Utility}

The satisfaction of the economic agent in economic 
science is measured by its utility. However, satisfaction is very comprehensive, and its measurement is difficult in an objective manner. On the other hand, the satisfaction of the economic agent is not only limited to matters of material nature but also to those of immaterial scope. One participant validates the idea by saying that there are economic studies that address happiness by means of proxy variables such as hope and life, welfare, happiness derived from work, et cetera. Another colleague has also given his contribution contrary to the idea of the impossibility of including variables of greater qualitative nature. He suggested the use of scales to match and quantify what appears to be only in the qualitative domain. He defended that: "we can use, for example, a scale of one to ten to study the various dimensions of well-being, working as instrumental variables that permit to do a simulation". As an intervener stated, subjectivity can also be measured economically through measuring scales that may have a comparative value amongst the degrees of this subjectivity. This perspective stimulates a broader discussion of the economic problem.

\section{Leadership: lead vs. guide}

One of the crosscutting values of economics is leadership. In today's society, competition, efficiency, leadership and sustainability are nuclear values in decision-making processes and economic behaviour. However, leadership should trigger the leader to consider dimensions that overflow the traditional values of the economy, such as empathy, commitment, compromise, responsibility, ethics and natural acceptance by others. This more dynamic perspective differentiates from the static leadership concept. In the current changing society, the features that once were considered important in a leader, as in the case of abuse of authority, on the interpersonal relationships within the Organisation, will give rise to other forms of putting into perspective and apply leadership. Increasingly, companies favour more assertive behaviours and consensual and look for a leader with "charisma" rather than the "enforcement" of his/her leadership. In this way, the leader should embody values that have a strong impact on the performance and productivity of the individual, which should not be neglected in economic activity. Consistent with this idea, one of the teachers felt that students perceive the leader through the lenses of leadership values as conveyed by the teacher. In this respect, he shared his experience in the area of social economics. This experience discussed the most valued skills in the labour market, where students felt that it was the ability to lead. The teacher replied: "to what extent a person would not have the courage to say he/she was not a leader, but that he/she is a good team element and that, in this case, would give an excellent contribution to the company?" According to the teacher, the students 'expressed surprise, as if the idea had never crossed their minds. Under these circumstances, we believe that from the point of view of the company it is quite important to have charismatic leaders as employees. Although these are not leaders, they are a benefit and advantage for the organisational performance. Hence, the economic value goes beyond strictly economic variables measurement and captures the results of variables considered as social ones. It is confidence within the company that leads employees to achieve higher levels of performance and productivity.

\section{Social responsibility}

Social responsibility is part of the characteristics of a charismatic leader. The concept of a leader, in the current economy, is overwhelmingly comprehensive because it includes all individuals engaged and committed to the team by simply being recognised by his co-workers, as stated by one of the participants of this study. Throughout the discussion, we envisioned answering the question of social commitment and to what extent the students can or should become an integral part of that commitment. In this respect, one of the professors mentioned the importance of awareness the student must have when handling the problems of society, stating that: "there is a world out there with which we have to worry about, because we live in it and the better this world is the better it will be for everyone else". The teacher believes that this approach raises awareness of students for social issues, a skill she considered of utmost importance to develop and which, in her opinion, could be combined with the objectives of the different disciplines of the Undergraduate Degree in Economics curriculum.

\section{Higher education orientation}

In the last decades, there emerged an academic discussion about the role of higher education in society. At first, the central role of the university was associated with the general guidelines of competition and excellence, measured by the construction of national and international rankings. These focused more on formal parameters of individual knowledge and marginalised interactive knowledge with the community, not being circumscribed to the business branch. Therefore, another approach that has been considered in the student's connection to society are the recommendations as offered by companies and employers on the best student's academic profile that better respond to the needs of the companies. However, one of the professors argued that this should not be the core mission of the University and university education, stressing that there should be a balance between this entrepreneurial claim and the social awareness of the student. Insofar the job 


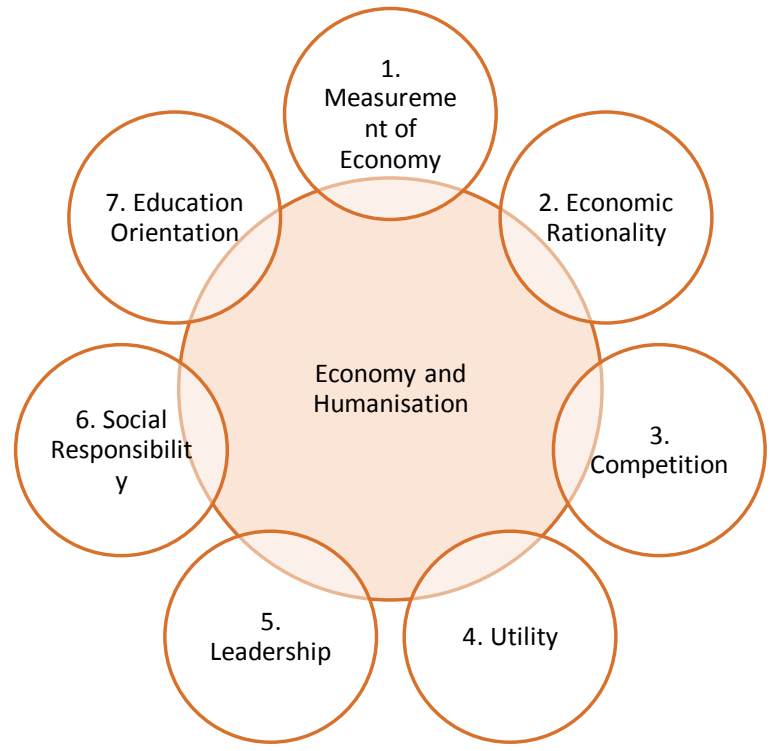

Figure 1. Diagram of identified categories. Source: Authors' model.

quality is concerned; we referred to an example in the field of work, where they resort to the use of indicators that reflect the extra well-being of the individual at work by introducing qualitative variables in the analysis. We are referring to the satisfaction of the employee in the performance of his/her task, the satisfaction of being at work, the relationship with co-workers and the relationship between family life and work. These issues of humanisation are not new and we can find their filaments in the guidelines of the Bologna Declaration, translated in international recommendations to be introduced in the curricula. (Figure 1)

The identified categories have a common denominator that is the possibility of making the academic curriculum in economics in a more humanised format to improve and consolidate social welfare. Thus, in all direct, collateral or transversal aspects of the teaching of economics, humanisation and approximation to society should always be present; both at the level of the curricular unit content and in the applied teaching-learning process and that may bring the students close to their citizenship. Notwithstanding some of the doubts we have dealt with, the participants in this study converged on the importance of the academic curriculum to meet the students' approach to the community, thereby humanising the university teaching-learning process. The question is, how do the different categories identified with the discussion and highlighted in this investigation interconnects by means of the common denominator that is the humanisation of higher education in general and the teaching of economics in particular?

Economic science seeks to distinguish itself from the other social sciences through the use of quantitative methods in its analysis, whilst favouring a quantitative approach as opposed to a qualitative one. Associated with this methodological principle, it counteracts the objectivity to the subjectivity of the economic decision, the rationality of the economic agent, shedding light on his lack of emotions when making decisions. Hence, the hesitations of some professors of the focus group, respectively of the area of econometrics, when they questioned how it would be possible to measure happiness in economics. However, it was not possible, as they stated, they failed to see interest in their introduction in the study of economics. However, because economic science seeks to be autonomous from other sciences, it is part of the social sciences, in which the behaviour of the individual is considered in interaction with the other individuals of his group and of groups with the other social groups. In a social perspective, the subjectivity of the economic agent is also part of its decision process making as an economic agent and its behaviour as a consumer or investor. It is interesting to mention that emotional states interfere in the rationality of choices, especially in the face of a decision in a context of uncertainty. Therefore, the measurement process in economics should contemplate the subjectivity associated with the emotional statuses of the economic agent. In the same line of thought, although the economic models have a privileged competition to the various forms of cooperation, efficiency seems to be enhanced and achieved by means of the interaction of the various economic players; hence, the values of competition should not be separated from those of cooperation for that matter.

The orientation of the teaching of economics has sought the dissemination of the prevailing paradigms. Therefore, it has privileged the value of competition and 


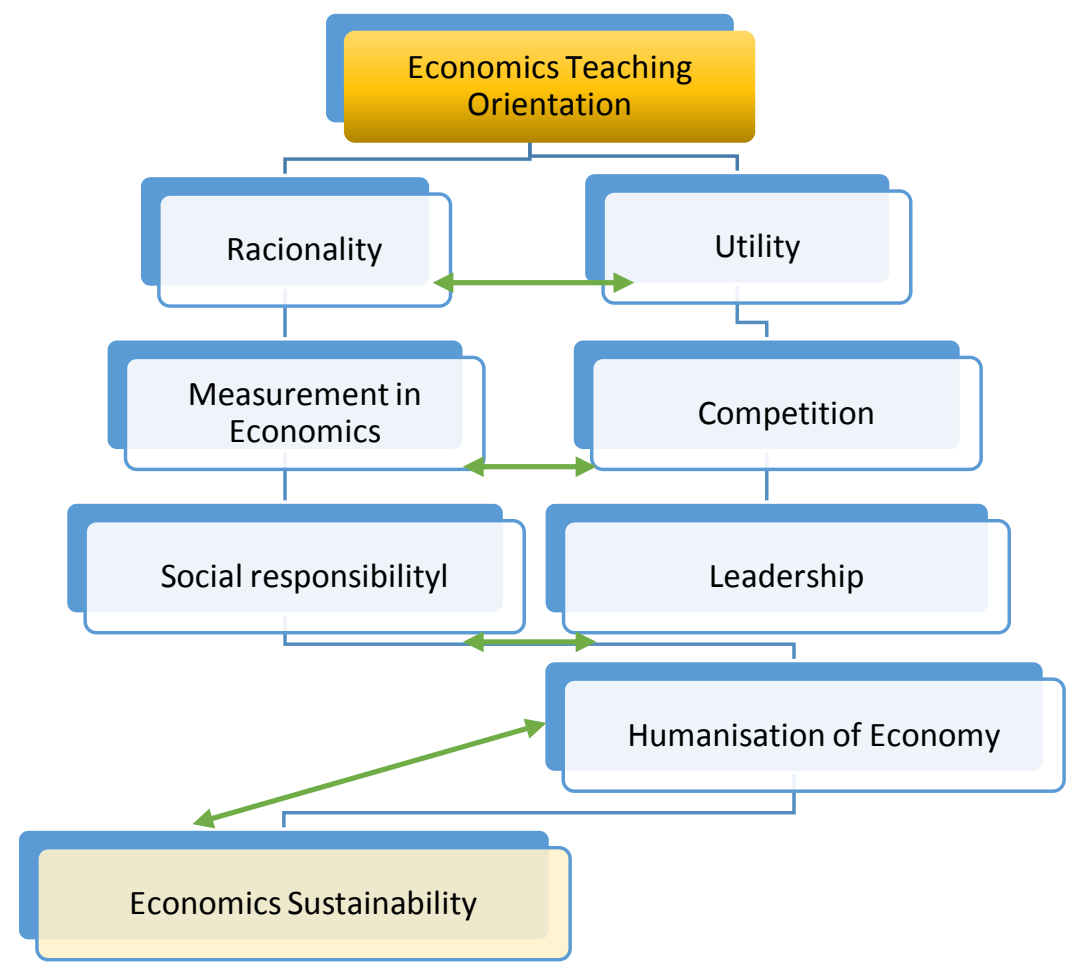

Figure 2. Diagram of association of categories. Source: Authors' model.

not the value of cooperation; it has given prominence to the satisfaction of the economic agent in its utilitarian form, and not on the basis of the values of happiness and solidarity of the individual in the group setting. In this way, the teaching of economics has given greater emphasis to the economic normativity of what should be.

Nevertheless, due to the markets' imperfections and to the externalities brought by these imperfections with particular emphasis on the environment, a new paradigm of the economy begins to gain prominence in the economic science, supported by the sustainability of Economy. It is worth mentioning that the economic paradigm has been embodying social responsibility values. Economics does also start to address social inequalities resulting from the application of economic neoclassic models and introduce new orienting aspects of teaching in Economics. One example is the understanding of what it is to be a leader in organisations and how the concept can be developed and applied in the teaching-learning process. All these new elements brought to the discussion of the teaching-learning of economics will contribute to the humanisation of this science, leading it to the acceptance of new forms of economic thought such as economic psychology and happiness in economics, ethics Economic and social responsibility, qualitative measurement in addition to quantitative measurement.

In this manner, and synthesising the functioning of the categories that resulted from the discussion, we understand that for the process of humanisation of the academic curriculum in economics, the analysis groups, constructed in categories, may result in interrelations according to the diagram of Figure 2 .

\section{DISCUSSION}

The University has a humanising mission in the production and dissemination of knowledge. It is a cell of development of humankind and a variable of inclusion and correction of market failures. Nevertheless, to improve the level of the University social responsibility, it is needed an in-depth discussion about the role and objectives of the University extension. Usually, this University extension is outside the curriculum and covers activities such as "social projection", "University extension", "relations with the community", "Interactive extension", "Extension work", "University society relationship" and "social commitment" (Domínguez, 2009:40).

The University extension covers services the University provides to the community through consultancy, preparation of technical advice, reports, monographs, inter alia. Nonetheless, the service learning should not be confused with those services, either the services per se and by way of its implementation and mission and can be considered a way to thank and give back to society part of the benefit obtained by the gratuitousness of the public education funding (Domínguez,2009). In this sense, it must be an explicit part of the teaching-learning process 
and help develop in the student the civic, human, social and personal dimensions within the moral and ethical responsibility standards (García and Cotrina, 2015).

According to the results of this study, the humanisation of the academic curriculum of economics seems to be an interesting process for the changing of the university teaching-learning process. Its importance offers dimensions thereby opening different directions that permit the creation of interactions between the university and the community and vice-versa. However, the process still finds strong obstacles arising from the lack of knowledge of the process itself, of what it is still considered as the core of a course in economics, its strong link with the labour market that predefines requirements in the economics education and to the society's competition paradigm that values more the student's school positioning and much less his formal involvement with the community. It should be highlighted that the economic paradigm itself is changing, due to the effects of economic globalisation, imported financial crisis, social inequalities that still persist and the new mentality that is being formed in this new generation of higher education students who are more attentive to social problems leading the university to construct bridges with the community. Universities do already collaborate with some community partnerships, such as non-profit associations. From the pragmatic point of view, such cooperation can occur through extracurricular partnerships and partnerships that are part of the curriculum (Bringle and Hatcher, 1996). According to these authors, the universities already have a significant number of students involved in extracurricular activities, as in the case of those who are involved in student unions, groups to welcome freshmen, groups of support and inclusion of the student, in non-profit organisations and religiousbased organisations, among others. Despite their social and altruistic character, such involvement does not match the service learning embedded in the curriculum and they have different objectives, given its punctuality, voluntary nature and absence of assessment. Yet, many universities are trying to incorporate into their plans of study service learning as an effective and mandatory component (Wurdinger and Rudolph, 2009), taking into account the benefits that the service learning methodology entails. Overall, and whilst resorting to the use of Eyler and Giles (1999), we can emphasise (i) the increase of self-knowledge, (ii) the increase of effectiveness in the absorption of knowledge, (iii) the ability to work in cooperation and with the other, (iv) the increased capacity of reflection and self-criticism, (v) the closer relationship with each other and with the community and (vi) the greatest respect for the suffering of others.

While a pedagogical methodology, the service learning seems to be an appropriate instrument to seek after the objectives of humanisation and social balance. Actually, its implementation allows for the bridging of the University with the community in the joint production of well-being, social cohesion, mutual respect and social reconstruction. On the other hand, its implementation in the community enables students to make a connection between the theoretical contents and their application, what contributes to modifying their feelings and attitudes in the context of an adverse society. This method contributes to their full development, steers cooperation and raises awareness about market failures. As it intersects with entrepreneurs, embraces a natural process of development and learning of values referred to as important by the professors who joined this investigation, such as the leadership, the responsibility concerning employment and their personal happiness along with the happiness in the workplace and within the community. At the same time, the implementation of service learning imposes a reflection on the current University extension. As a rule, the University extension does primarily entail the provision of teaching services, which juxtaposes itself to the collaborative and responsible participation of the student with the surrounding community. Yet, it should be noted that the service learning also contributes to bridging responses to the solicitations and expectations of companies in relation to the role of the University and the student profile because the service learning helps the student to internalise his/her social responsibility and puts it into practice in the company, which leverages his/her performance.

Regardless of the methodology of service learning is in a phase of reflection in what concerns curricular innovation, it does offer the high potential of development for the University because it enhances the connection between the University's mission and the interests of the community and of the companies. For the teaching of Economics, it emerges as an added value in the new economy that includes variables usually disregarded by the traditional economic approach, such as the economics of happiness, which is built on values of solidarity, altruism, cooperation, respect, responsibility, emotional and spiritual balance.

For such reasons, the Service Learning must be within the University linked to University extension to bridge the University and the community, steering their cooperation around the social well-being, according to Figure 3.

\section{CONCLUSION}

The process of humanisation of the curriculum in economics, as underlined in this study, can be developed and implemented through a Service Learning methodology. We believe in this methodology because it is a dynamic process that brings students closer to the community, which improves their autonomy and solidarity competences and reinforces their intra-individual and interpersonal relationships.

Issues such as social responsibility, leadership, and sustainability of the economy find application and 


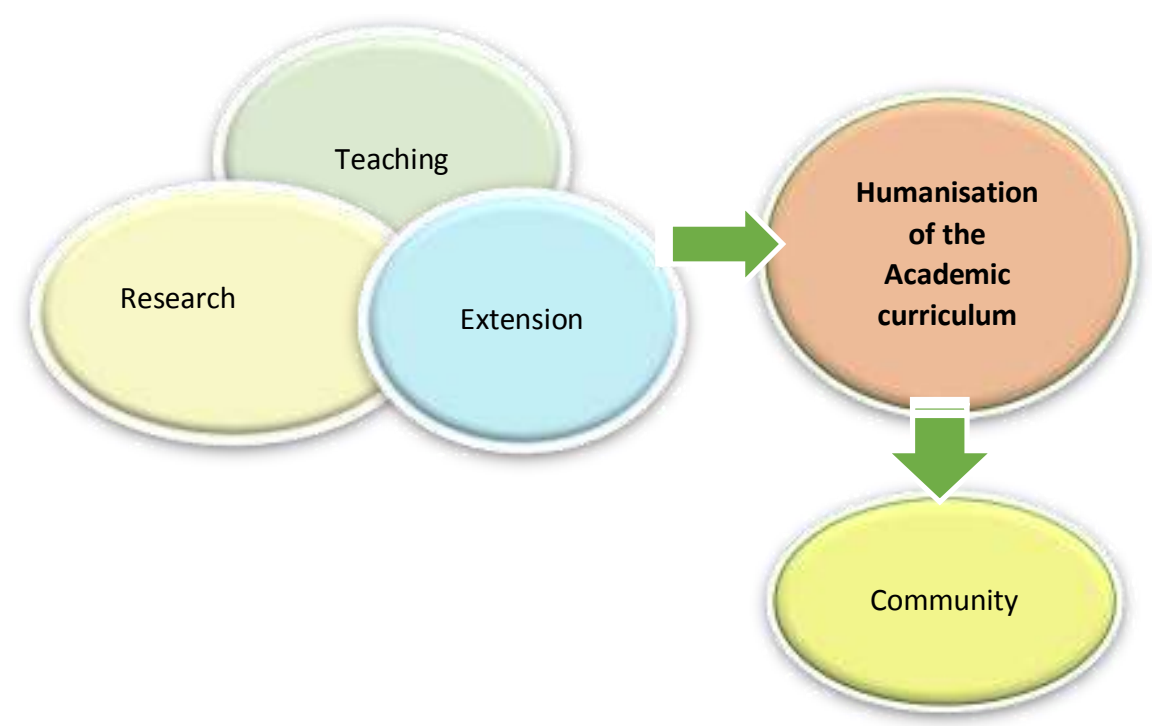

Figure 3. Humanisation of the academic curriculum with the Service-learning in Higher Education. Source: Adapted from Tapia (2013).

resonance in this link between students and the community fomented by Service Learning. This methodology does not jeopardize the values of the current economic and social paradigm, but it rather seeks to improve it by introducing feelings and values as important as cooperation, attentive listening, awareness of social causes, predisposition to working in groups, where competition and cooperation are seen as two complementary elements of economic performance. In this light, the teachers who participated in this investigation raised as important values of humanisation social commitment, leadership and social harmony. It was conducted a reflection on the methodological bases of the traditional economy and introduced variables of personal and social nature, with possible explanatory potential economic models. It was also pondered the possibility of introducing these values in the curricula' syllabus and how could the process be materialised. Its introduction would contribute in some way to the humanisation, although one would have to surpass obstacles in what regards the formatting of the course units, which do still enshrine some kind of programmatic rigidity.

\section{REFERENCES}

Bamber P, Hankin L (2011). Transformative learning through service learning: no passport required. Educ. Train. 53(2/3):190-206.

Bardin L (1977). L'analyse de Contenu. Presses universitaires. France.

Bjornesta A, Mims G, Mims M (2016). Service learning in schools: Training counsellors for Group Work. The J. Special. Group Work 41(3):190-280.

Bringle R, Hatcher J (1995). A service-learning curriculum for faculty. Michigan J. Commun. Serv. Learn. 2(3):112-122.

Bringle R, Hatcher J (1996). Implementing Service Learning in Higher Education. J. Higher Educ. 67(2):221-239.
Burke A, Bush M (2013). Service Learning and criminal justice: an exploratory study of student perceptions. Educ. Rev. 65(1):56-69.

Celio Cl, Durlak J, Dymnicki A (2011). A Meta-analysis of the Impact of Service-Learning on Students. J. Exper. Educ. 34(2):164-181.

Copaci I, Rusu A (2016). Trends in Higher Education Service Learning Courses for Pre-Service Teachers: A Systematic Review. ERD 2016: Education, Reflection, Development, Fourth Edition.

Desplaces DE, Steinberg M, Coleman S, Kenworthy-U'Ren A (2006). A Human Capital Model: Service-Learning in the Micro Business Incubator Program. Michigan J. Commun. Serv. Learn. pp. 66-80.

Domínguez MJ (2009). Responsabilidad Social Universitaria. Humanismo y Trabajo Social 8:37-67.

Eyler J, Giles DE (1999). Where's the learning in service-learning? San Francisco: Jossey-Bass.

Eyler J, Giles DE, Schmiede A (1996). A practitioner's guide to reflection in service learning: Student voices and reflections. Nashville, TN: Vanderbilt University.

García GM, Cotrina GM (2015). El aprendizaje y servicio en la formación inicial del profesorado: de las prácticas educativas críticas a la institucionalización curricular. Profesorado - Revista de currículum y fornación delprofesorado, 19(1):8-25.

Guerra I (2006). Pesquisa Qualitativa e Análise de Conteúdo-Sentidos e Formas de Uso. Princípia, Cascais.

Hegarty N, Angelidis $\mathbf{J}$ (2015). The Impact of Academic ServiceLearning as a Teaching Method and its Effect on Emotional Intelligence. J. Acad. Ethics 13(4):363-374.

Heffernan K (2001). Service-Learning in Higher Education. J. Contemp. Water Res. Educ. 119(1):2-8.

lerullo M, Maglioni C (2015). Investigación participative y transformación social: reflexionando desde la experiencia. In Herrero M, Tapia M (2015). Actas de la III Jornada de Investigadores sobre aprendizaje-servicio, CLAYSS-Red Iberoamericana de aprendizajeservicio, Buenos Aires, Argentina, pp. 41-46.

Kiely R (2005). A transformative learning model for service-learning: a longitudinal case study. Michigan J. Commun. Serv. Learn. 12(1):522.

Lee RL (2012). Experience is a Good Teacher: Integrating Service and Learning in Information Systems Education, J. Inform. Syst. Educ. 23(2):165-176.

NCES - National Center for Education Statistics (1999). Service learning and community service in $\mathrm{K}-12$ public schools. U.S. Department of Education: office of education research and 
improvement. NCES 1999-043.

Patton M (2002). Qualitative Research and evaluation methods. Newbury Park, CA: Sage Publications.

Podeschi RJ (2016). Building I.S. Professionals through a Real-World Client Project in a Database Application Development Course, Inform. Syst. Educ. J. (ISEDJ) 14(6):34-40.

Rudy R, Popova M, Linz (2010). The Context of Current Content Analysis of Gender Roles: An Introduction to a Special Issue. Sexual Roles, 62:705-720.

Swords A, Kiely R (2010). Beyond Pedagogy: Service Learning as Movement Building in Higher Education. J. Commun. Pract. 18(23):148-170.

Tapia MN (2010). Calidad Académica $Y$ responsabilidad Social: el aprendizaje servicio como puente entre dos culturas universitarias. In Martínez, M. (ed) (2010). Aprendizaje Servicio y responsabilidad social de las Universidades. Barcelona, Editorial Octaedro / ICE-UB: 27-56.

Tapia MN (2013). Presentación, 16으 Seminario Internacional de aprendizaje y servicio solidario. CLAYSS, Buenos Aires, 22 de agosto de 2013.2 Available at http://www.clayss.org.ar/XVI_seminario/material_22/1_AperturaNT.pdf, consulted in 19-02-2018.
Wang Y, Rodgers R (2006). Impact of Service-Learning and Social Justice Education on College Students' Cognitive Development, NASPA J. 43(2):316-337.

Wilcox E, Zigurs I (2003). A Method for Enhancing the Success of Service-Learning Projects in Information Systems Curricula. Inform. Syst. Educ. J. 1 (17). Available at http://isedj.org/1/17/. ISSN: 1545679X. (Also appears in The Proceedings of ISECON 2003: §3431. ISSN: 1542-7382.), consulted in 14-03-2018.

Yorio PL, Ye F (2012). A Meta-Analysis on the effects of ServiceLearning on the Social, Personal, and Cognitive Outcomes of Learning. Acad. Manage. Learn. Educ. 11(1):9-27.

http://sciencewebpublishing.net/jerr 